\title{
HOVERING MALES OF HYBOMITRA CINCTA (FABRICIUS) (DIPTERA, TABANID无)
}

\author{
By Norman S. BaIley \\ Boston University
}

In a recent paper (Annals, E.S.A., December, 1948) I reviewed the literature dealing with the hovering and mating of Tabanids. The observations recorded in this item corroborate the opinion then expressed that hovering is primarily a male activity among the horseflies. Brimley and Sherman (1908) had previously noted the males of this species so engaged. The following data reveal some of the conditions under which Hybomitra cincta (Fabr.) hovers.

During the 1948 season I was regularly in the field from early June until October. On July 7 th I was pleased to observe and net a hovering male of Hybomitra cincta at a station that I had recently discovered to be of considerable entomological interest in other respects. Consequently, an effort was made to visit the locality at frequent intervals throughout the summer and early fall. Specimens of $H$. cincta were seen and taken on nine occasions from July 7 th to July 29 th inclusive. After the last date mentioned none were seen. There were a few days within the period indicated when none of them was observed. Of further interest is the fact that not one female was captured, although, with only one or two exceptions, every fly of that species was successfully netted. Probably females were not far away, however.

A total of 28 hovering males were taken. Seven is the largest number captured on any one day. The accompanying table shows that they hover from $8: 30$ to $9: 40$ a.m. and from 1:30 to 5:10 p.m. (Eastern Daylight Saving Time.) ${ }^{1}$ However, no flies were taken between 10 a.m. and $1: 30$ p.m. Tabulated field notes also suggest that hovering goes on within rather wide limits (for the

1 One hour later than Eastern Standard Time. 
season, i.e.) of temperature, relative humidity, and light conditions. Another year an attempt will be made to accumulate more detailed information of this nature.

Table 1.

\begin{tabular}{|c|c|c|c|c|}
\hline Date & Hour & $\begin{array}{l}\text { Males } \\
\text { taken }\end{array}$ & Light & Remarks \\
\hline $7-7-48$ & $3: 30$ p.m. & 1 & & \\
\hline 8 & $9: 40$ a.m. & 3 & & \\
\hline 15 & $2: 30-3: 30$ p.m. & 7 & & \\
\hline 17 & $12: 30-1: 30$ p.m. & 0 & & \\
\hline 18 & 8:30-8:45 a.m. & 2 & & $\begin{array}{l}\text { Warm, humid, high } \\
\text { clouds. }\end{array}$ \\
\hline 19 & 3:45 p.m. & 4 & & High overcast. \\
\hline 20 & $\begin{array}{l}1: 30 \text { p.m. } \\
2: 20 \text { p.m. }\end{array}$ & $\begin{array}{l}3 \\
1\end{array}$ & $10,500 \mathrm{ft}$. candles & \\
\hline 21 & $12-12: 30$ p.m. & 0 & $5,500-12,000$ ft. e. & $\begin{array}{l}\text { Very warm, humid, } \\
\text { cloudy. }\end{array}$ \\
\hline 22 & $\begin{array}{l}\text { 5:10 p.m. } \\
\text { 4:00 p.m. }\end{array}$ & $\begin{array}{l}2 \\
1\end{array}$ & $3,500 \mathrm{ft}$. candles & Missed a third fly. \\
\hline 27 & 2:05 p.m. & 0 & $6,000 \mathrm{ft}$. candles & \\
\hline 29 & 2:00 p.m. & 4 & $10,500 \mathrm{ft}$. candles & Hot and clear. \\
\hline
\end{tabular}

The light values were all determined with a G-E exposure meter (Model DW-58) using the 100:1 incident light mask. Readings were taken with the meter held vertically (openings up) at shoulder height. Values of $300: 1$ may be obtained with this instrument by covering two of the three mask apertures. This is necessary for readings above 7,000 foot candles.

The station lies in the Neponset River Reservation along Route 128 in Canton, Massachusetts. The area is somewhat below the road level and the plant cover consists of clumps of young deciduous trees, shrubs, and evergreens with grassy glades interspersed. A bridle path, with evidence of slight usage, makes an irregular loop through the part under consideration. It was only beside the bridle path in two of the larger open places that hovering flies were seen. The two sites are separated by a wooded area a few hundred yards wide. About $80 \%$ of the flies were taken at the spot nearest the highway.

Here the first male was encountered. He was hovering 
in mid-afternoon sunlight and the rich color contrast of his black and red-orange banded abdomen attracted my notice. This species hovers just over the herbs and low shrubs at heights ranging conveniently from 1-4 feet above the ground. My first attempts with the net were unsuccessful. However, I soon discovered a method that was nearly always effective. After approaching slowly within reach, the net may be raised gradually into a position directly beneath the fly. Then, with a swift upward sweep he is readily captured. Hovering flies are not easily disturbed if a person moves unhurriedly. Even if they escape the net at first, they almost invariably return to hover in approximately the same position. Therefore, although they usually evade a head-on or a down sweep, they may be readily captured by the casual approach from beneath.

Hovering is an individual affair for this species. In contrast to the mass hovering of Tabanus nigrovittatus Macquart (Bailey, 1947, 1948), usually no more than one or two $H$. cincta males were seen so engaged at the same time. On the few occasions when two or three flies were found hovering in an area, they were always some yards apart and appeared to be acting quite independently.

In conclusion, attention should be called to the fact that this is the first time that hovering during both the morning and afternoon has been recorded for a particular species, as far as I am aware.

\section{Literature Cited}

Bailey, N. S. 1947. Psyche, 54(1) : 62-64. 1948. Annals, Ent. Soc. Amer., December (in press).

Brimley, C. S. and Sherman, F., Jr. 1908. Ent. News, 19: 172.

Philip, C. B. 1947. Am. Midl. Nat., 37 (2) : 257-324. 

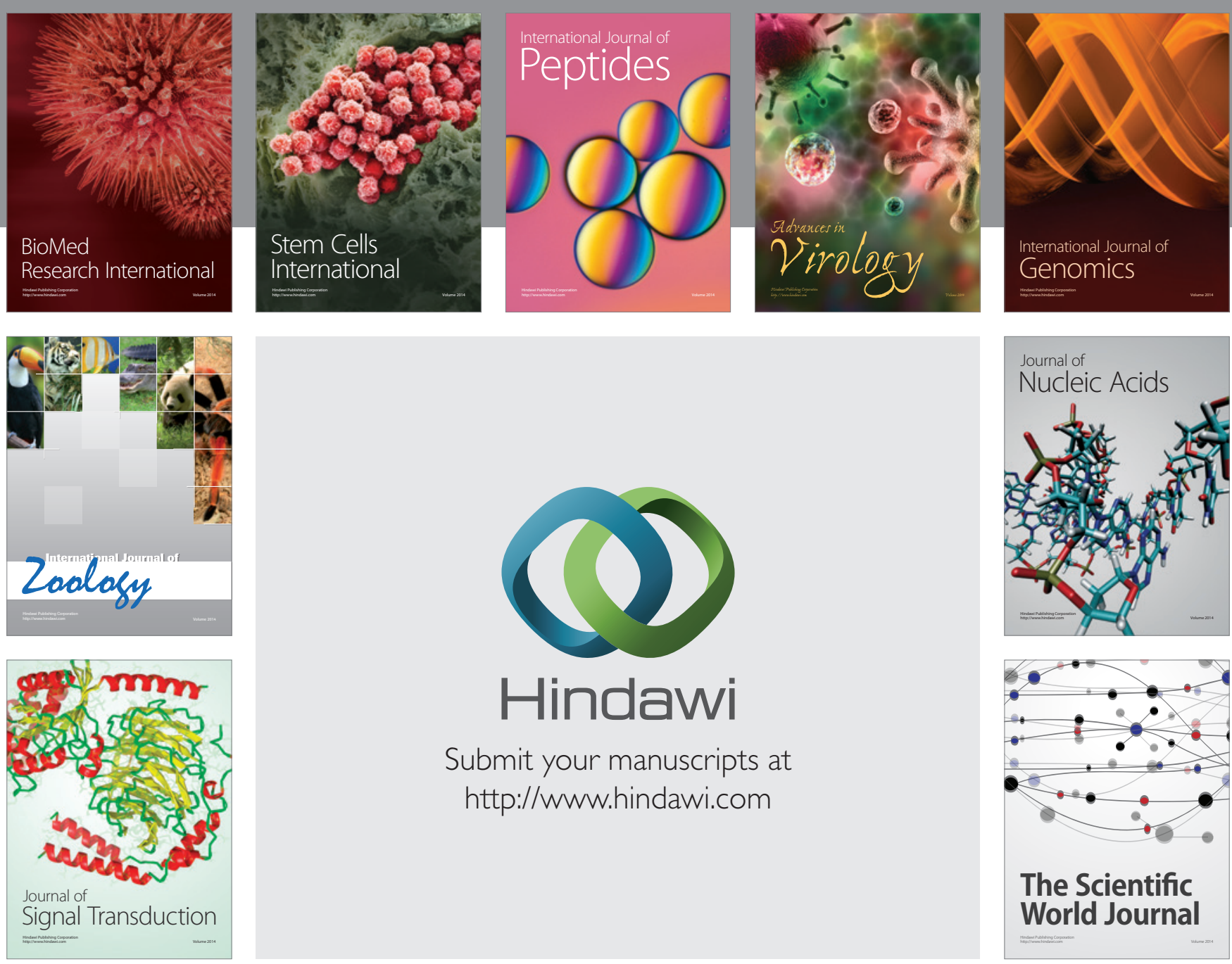

Submit your manuscripts at

http://www.hindawi.com
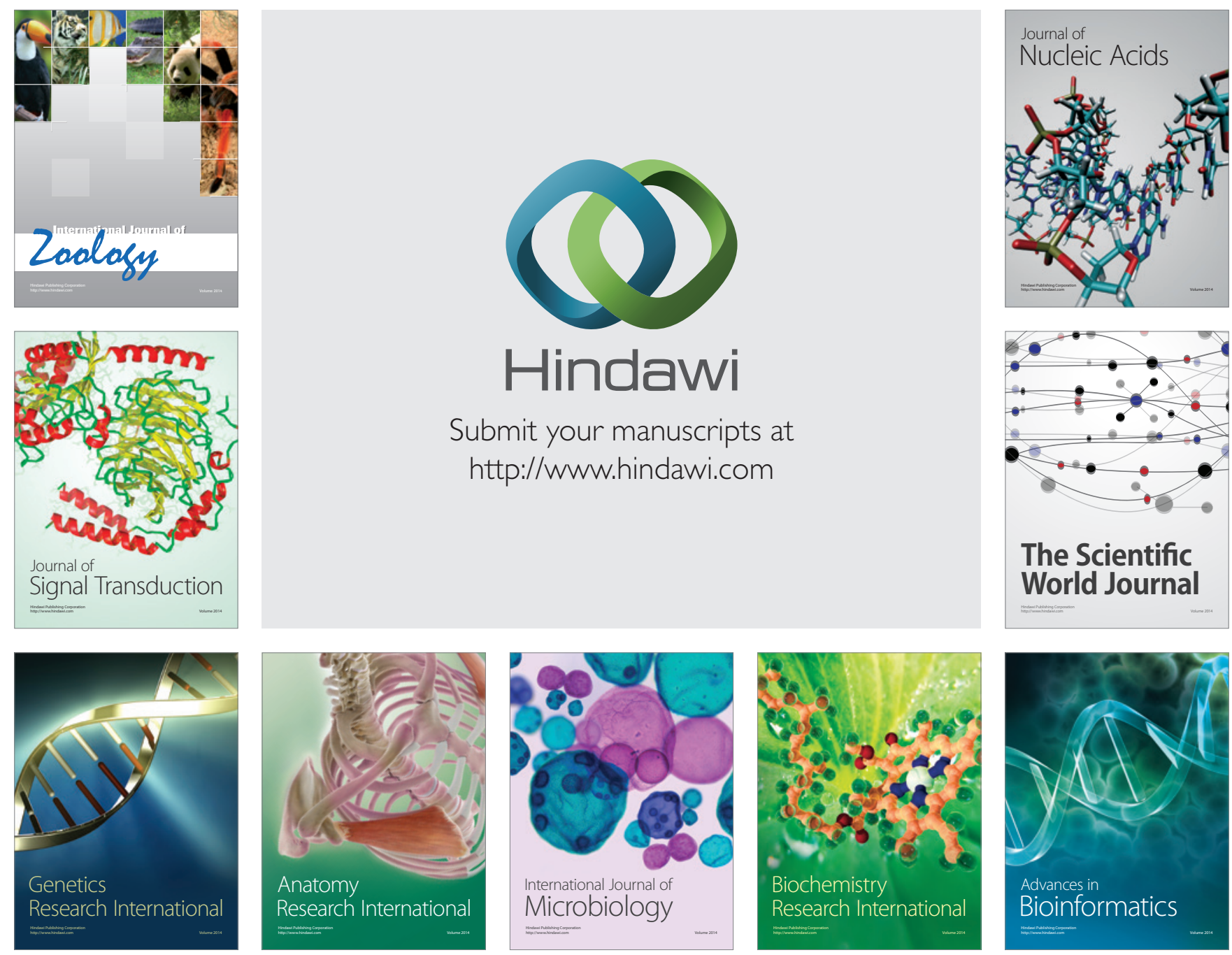

The Scientific World Journal
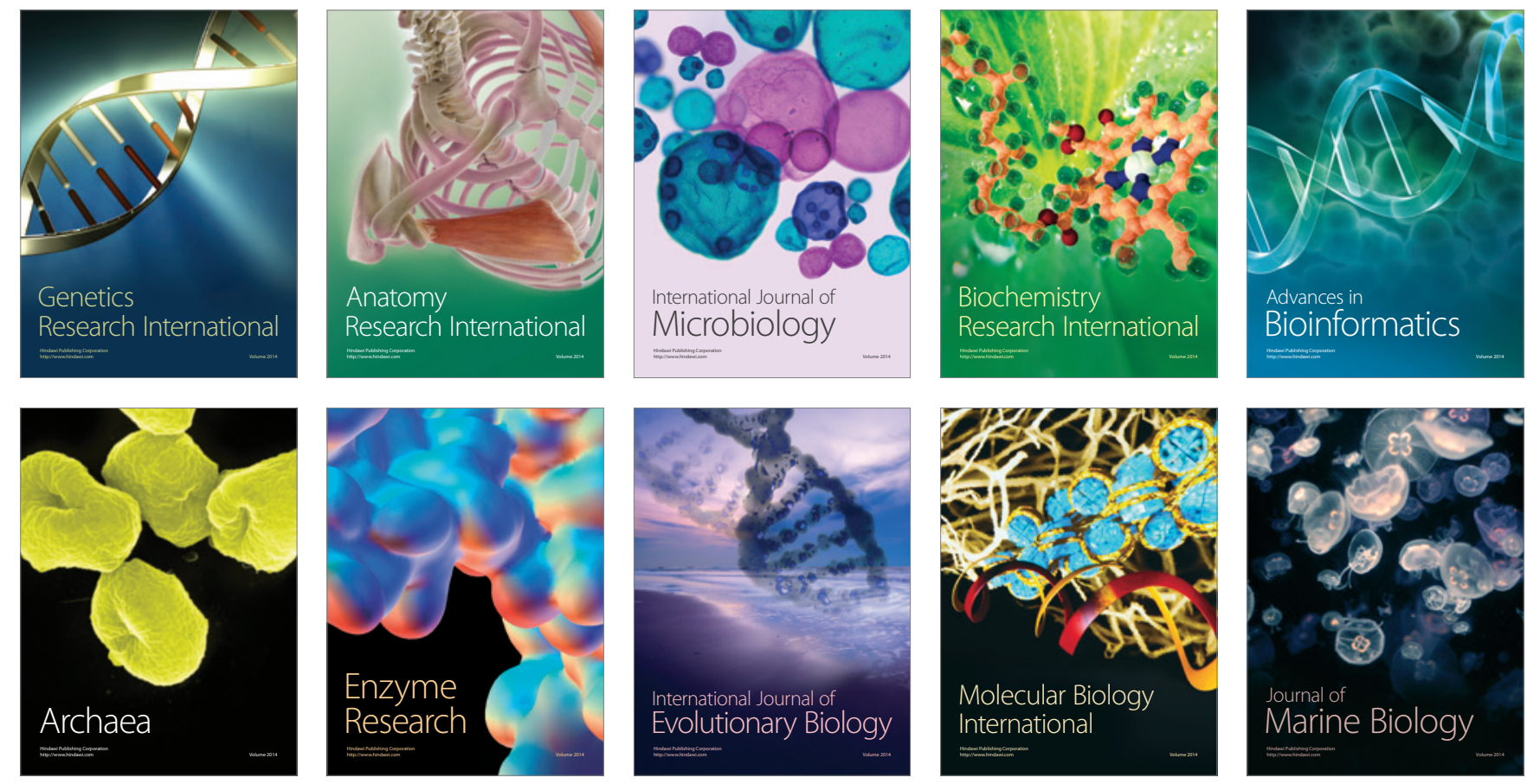